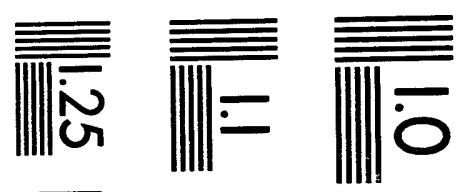

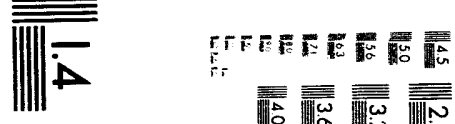

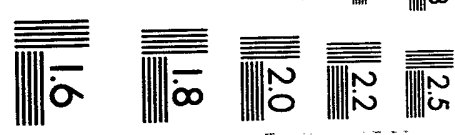



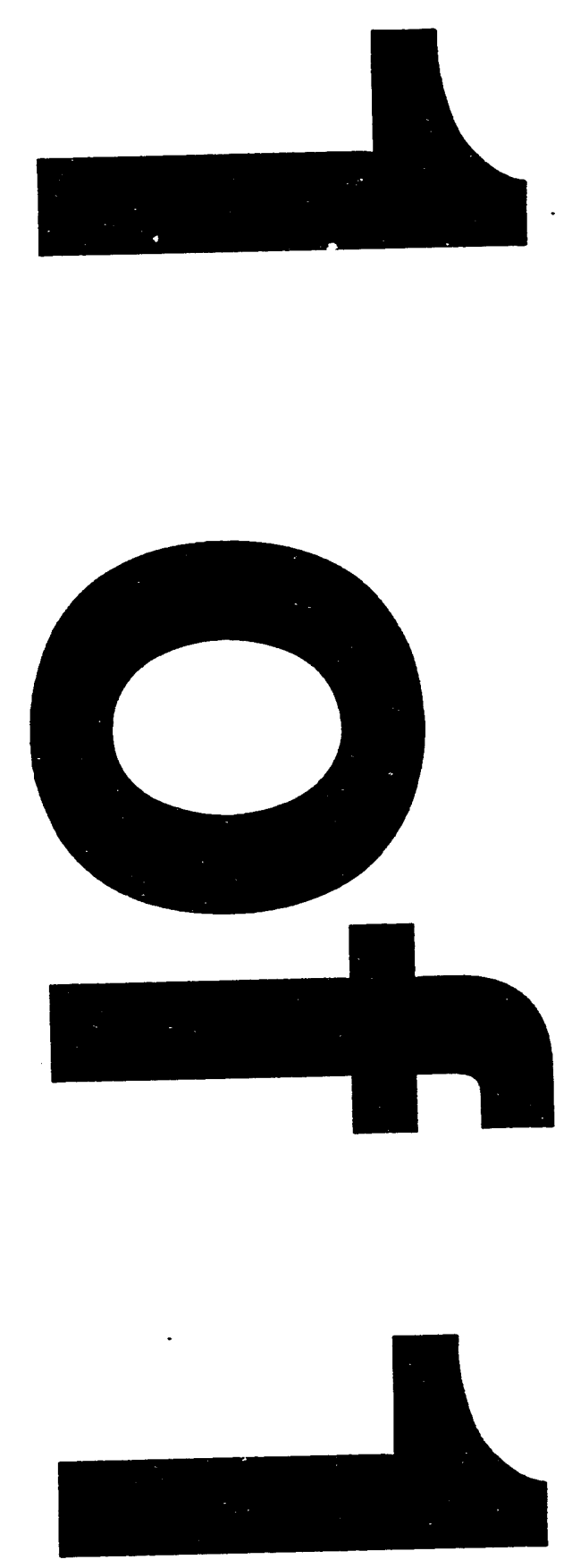
Energy Systems Environmental Restoration Program ORNL Decontamination and Decommissioning Program

\section{Annual Summary Report of the Decontamination and Decommissioning Surveillance and Maintenance Program at Oak Ridge National Laboratory for Period Ending September 30, 1993}

Date Issued-November 1993

Prepared for

U.S. Department of Energy

Office of Environmental Restoration and Waste Management under budget and reporting codes EW 20 and EX 20

Prepared by

Waste Management and Remedial Action Division

OAK RIDGE NATIONAL LABORATORY

Oak Ridge, Tennessee 37831-6285

managed by

MARTIN MARIETTA ENERGY SYSTEMS, INC.

for the

U.S. DEPARTMENT OF ENERGY

under contract DE-AC05-84OR21400

DISTMBUTION OF THIS DOCUMENT IS UNUMITE 


\section{Author Affiliations}

M. K. Ford and L. Holder, Jr., are members of the Waste Management and Remedial Action Division at the Oak Ridge National Laboratory, Martin Marietta Energy Systems, Inc. 


\section{CONTENTS}

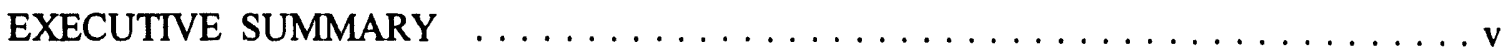

1. INTRODUCTION $\ldots \ldots \ldots \ldots \ldots \ldots \ldots \ldots \ldots \ldots \ldots \ldots \ldots \ldots \ldots$

2. SURVEILLANCE AND MAINTENANCE PLANNING $\ldots \ldots \ldots \ldots \ldots \ldots \ldots$

2.1 MOLTEN SALT REACTOR EXPERIMENT CONTAMINATION

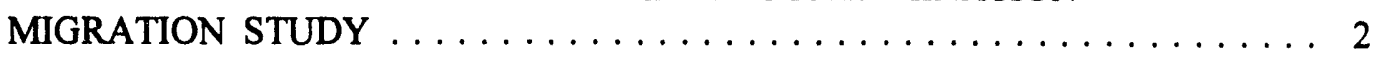

2.2 OCCUPATIONAL SAFETY AND HEALTH ACT COMPLIANCE

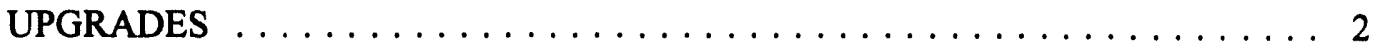

2.3 MOLTEN SALT REACTOR EXPERIMENT COMPLIANCE WITH

APPLICABLE DOE ORDERS $\ldots \ldots \ldots \ldots \ldots \ldots \ldots \ldots \ldots \ldots$

3. ROUTINE SURVEILLANCE AND MAINTENANCE $\ldots \ldots \ldots \ldots \ldots \ldots \ldots \ldots$

3.1 SURPLUS REACTOR FACILITIES SURVEILLANCE AND

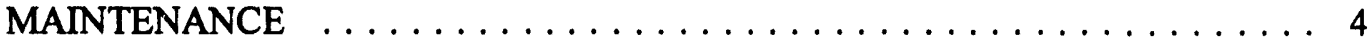

3.1 .1 Molten Salt Reactor Experiment $\ldots \ldots \ldots \ldots \ldots \ldots \ldots \ldots \ldots \ldots \ldots$

3.1 .2 Oak Ridge Research Reactor $\ldots \ldots \ldots \ldots \ldots \ldots \ldots \ldots \ldots \ldots$

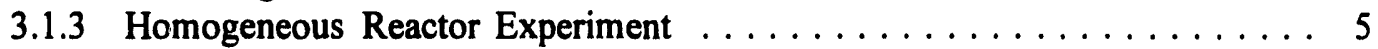

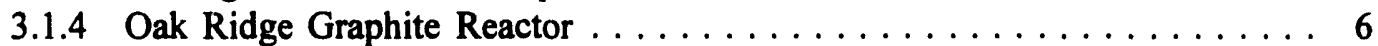

3.1.5 Low-Intensity Test Reactor . . . . . . . . . . . . . . . . 6

3.2 OTHER SURPLUS FACILITIES SURVEILLANCE AND

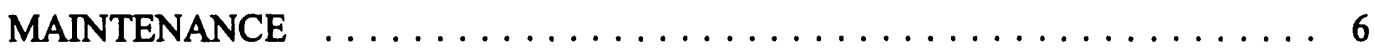

3.2.1 High Level Chemical Development Laboratory $\ldots \ldots \ldots \ldots \ldots \ldots$

3.2.2 Old Hydrofracture Facility (Building 7852) $\ldots \ldots \ldots \ldots \ldots$

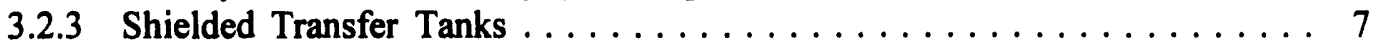

3.2.4 Fission Product Pilot Plant (Building 3515) $\ldots \ldots \ldots \ldots \ldots \ldots \ldots \ldots$

3.2.5 Waste Evaporator Facility (Building 3506) $\ldots \ldots \ldots \ldots \ldots \ldots \ldots \ldots$

3.2.6 Fission Product Development Laboratory $\ldots \ldots \ldots \ldots \ldots \ldots \ldots$

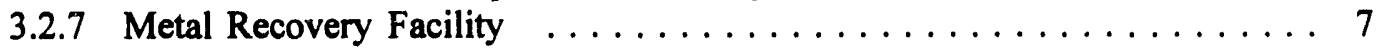

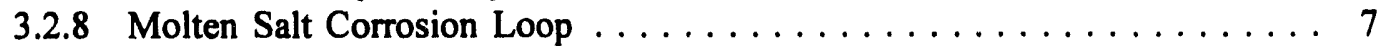

3.2.9 Coolant Salt Technology Facility $\ldots \ldots \ldots \ldots \ldots \ldots \ldots \ldots \ldots \ldots$

3.2.10 Decontamination Facility $\ldots \ldots \ldots \ldots \ldots \ldots \ldots \ldots \ldots \ldots \ldots \ldots$

3.2 .11 Storage Tank $\ldots \ldots \ldots \ldots \ldots \ldots \ldots \ldots \ldots \ldots \ldots$

4. SPECIAL MAINTENANCE PROJECTS $\ldots \ldots \ldots \ldots \ldots \ldots \ldots \ldots \ldots \ldots$

4.1 MOLTEN SALT REACTOR EXPERIMENT CONTAMINATION

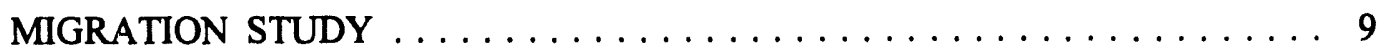

4.2 OSHA COMPLIANCE UPGRADES $\ldots \ldots \ldots \ldots \ldots \ldots \ldots \ldots \ldots$

4.3 SAFETY ANALYSIS REPORT UPGRADE PROGRAM $\ldots \ldots \ldots \ldots \ldots \ldots$

4.4 OAK RIDGE RESEARCH REACTOR INSTRUMENT UPGRADE . . . . . . 10

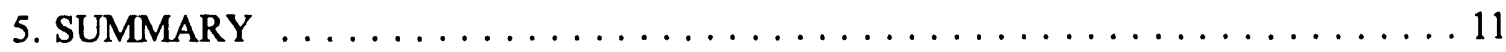




\section{EXECUTIVE SUMMARY}

The Surplus Facilities Management Program and Defense Facilities Decommissioning Program were established at ORNL in 1976 to provide collective management of all surplus sites under ORNL's control on the Oak Ridge Reservation. Some 34 facilities, classified into 3 civilian-related and 8 defense-related projects, are currently managed by the recently integrated Decontamination and Decommissioning Program. Support includes (1) surveillance and maintenance planning; (2) routine surveillance and maintenance; and (3) special maintenance projects. This report documents routine surveillance and maintenance, special projects, and special maintenance performed on these facilities for the period of October 1992 through September 1993. 


\section{INTRODUCTION}

The Oak Ridge National Laboratory (ORNL) Decontamination and Decommissioning (D\&D) Program has continued to provide surveillance and maintenance (S\&M) support for 34 surplus facilities. The objectives are to (1) ensure adequate containment of residual radioactive materials remaining in the facilities, (2) provide safety and security controls to minimize the potential hazards to on-site personnel and the general public, and (3) manage the facilities in the most cost-effective manner while awaiting decommissioning. This support has included work in three principal areas: (1) S\&M planning, (2) routine S\&M, and (3) special projects designed to correct serious facility deficiencies beyond the scope of routine maintenance. 


\section{SURVEILLANCE AND MAINTENANCE PLANNING}

\subsection{MOLTEN SALT REACTOR EXPERIMENT CONTAMINATION MIGRATION STUDY}

Since shutdown of the Molten Salt Reactor Experiment (MSRE) in 1969, the fuel and flush salts have been surveyed and maintained as a rational and safe approach to near-term storage. Surveys of the past several years have shown an unusually large increase in background radiation level in the North Electric Service Area (NESA), and an unidentified white smoke or vapor that was emitted from an opened pipe fitting in the Vent House. Based on these two conditions, the following actions have been pursued. First, the annual reheats have been suspended until after the balance of the study and subsequent follow-up corrective actions are completed. Secondly, baseline measurements for ${ }^{232} U$ and daughter activity at the drain tank purge lines have been followed (qualitatively). Also, the east cell face has been mapped for ${ }^{137} \mathrm{Cs}$ (i.e., Barium-137m) for localization of its source (ultimately for a fixed ratio with ${ }^{232} \mathrm{U}$ ). Follow-up actions may include reinstatement of a helium purge on the drain tanks and application of external heat at the entry point. For now, a gas/aerosol sample will be taken from the Vent House line that once released a trace of alpha activity and white smoke or vapor and will be analyzed for ${ }^{235} \mathrm{U},{ }^{238} \mathrm{U}$, fluorine, and fluorine compounds. Subsequent actions will be initiated after these data are obtained and observations are completed.

\subsection{OCCUPATIONAL SAFETY AND HEALTH ACT COMPLIANCE UPGRADES}

Beginning in FY 1991, in response to audit findings and recommendations by the U. S. Department of Energy (DOE), Occupational Safety and Health Act (OSHA) upgrades were initiated to assess surplus facilities in terms of environmental, safety, and health issues associated with worker safety. Some of these findings that were not addressed in FY 1992 involve corrective actions at the Low-Intensity Test Reactor (LITR) and ine Homogeneous Reactor Experiment (HRE). Many of these findings require interpretation from the ORNL OSHA Department for applicability and the use of a graded approach appropriate for surplus facilities.

\subsection{MOLTEN SALT REACTOR EXPERIMENT COMPLIANCE WITH APPLICABLE DOE ORDERS}

In January 1992, DOE requested that Ebasco Services, Inc., perform an evaluation of the MSRE to assess whether the current surveillance and maintenance program for the facility, procedures, and physical structure of the MSRE are in compliance with applicable rules and regulations as well as DOE orders. This report was published on May 21, 1993.' Ebasco concluded that existing documentation on the current condition of the MSRE facility is inadequate and that the safety of this facility has not been adequately evaluated and documented. The report also states that there was a delay in investigating the significant unexplained increase in radiation levels in the facility and that there was a postponement of the

${ }^{1}$ MSRE Compliance Assessment, Ebasco Services, Inc., May 21, 1993. 
annual reheat of fuel and flush salts. In addition, the report noted discrepancies in radiological and contamination area postings as compared to private industry standards for radiological posting.

Currently, the D\&D Program is pursuing actions to address deficiencies at MSRE. An update to safety documentation in the form of a revision to the current Nuclear Safety Review (NSR) is nearing completion. This document will provide a basis for the continued storage or removal of the fuel salts at the MSRE by virtue of the integrity and stability of the salt and current facility capabilities and status. Also, the investigation of the anomalies in migration of the contamination is in progress, and upcoming sampling of the drain tank environment and gamma scanning of several areas will allow observations and resulting conclusions to be drawn. Finally, postings at MSRE are consistent with postings at other ORNL and DOE installations. 


\section{ROUTINE SURVEILLANCE AND MAINTENANCE}

\subsection{SURPLUS REACTOR FACILITIES SURVEILLANCE AND MAINTENANCE}

\subsubsection{Molten Salt Reactor Experiment}

At the MSRE this year, particulate retention efficiency was tested for all three filter banks of the cell ventilation system, and the system was approved for continued service. Maintenance performed on the cell vent system this year included replacement of all sheaves and belts on the fan motors. Approximately $4 \mathrm{ft}^{3}$ of contaminated waste was removed from the high bay area of the MSRE and placed into tumulus storage. Devices for protection against water intrusion into the drain tank cell were reviewed; this review included a visual inspection of selected lines that were capped during the initial shutdown of MSRE. This effort was conducted to update the Nuclear Safety Review for the MSRE. The Joy air compressor, which supports instrumentation for safe facility shutdown status at MSRE, was overhauled and returned to service. The 50-amp breakers that feed power to the heaters on each drain tank were administratively locked out to prevent accidental energizing of the fuel salt heaters. A quality assurance (QA) audit of lockout/tagout at MSRE was conducted this year to address implementation of new QA requirements. Several of the tags that had been applied were found to be excessive and were replaced with administrative tags rather than the more restrictive lockout/tagout tags. Dye tests were performed on floor drains to confirm that the drains had been capped or plugged prior to or following the FY 1992 Drain Survey for ORNL. Two drains in the facility that had the potential to drain to nonpermitted locations were capped.

A subcontractor is currently completing the final revisions on the current NSR of the Molten Salt Reactor Experiment. In support of that effort, work was completed on providing a technical basis for assurance that criticality is not possible for the current configuration of the stored fuel salt at the MSRE. These data were provided to the ORNL Office of Operational Readiness and Safety. The revised NSR will support the safety documentation for the fuel salt at MSRE.

A complete list of MSRE operational files was transferred from the custodial care of the Engineering Technology Division to the Waste Management and Remedial Action Division (WMRAD) for management during S\&M and subsequent (D\&D) activities.

Visual inspection of the interior of the Tank 7503A at the MSRE was performed by videotaping with a remote camera. Although past correspondence from MSRE operations personnel indicated that it contained approximately $1500 \mathrm{gal}$ of residue from past MSRE operations, the tank was found to be empty. No degradaxion was noted, and a subsequent grab sample was taken of the dry residue on the tank bottom for isotopic metals analysis. No RCRA materials were identified in the sample analysis results. The results indicated the presence of ferrous and aluminum oxides.

\subsubsection{Oak Ridge Research Reactor}

The QA Department performed dioctylphthalate (DOP) tests on the normal off-gas filters and all lab hoods in the facility. The filters tested satisfactory except for the lab hoods, which were rejected because of insufficient flow. The lab hood dampers were adjusted to allow acceptable ventilation, and the previous rejection was removed. A water purification method labeled "feed 
and bleed" was conducted in the Oak Ridge Research Reactor (ORR) Pool to replenish degrading demineralized water without treatment using resin beds. Repairs were performed to several leaks on the ORR roof. Above-ground storage tanks at several support buildings at ORR were assessed by the Environmental Compliance group and declared empty; that is, these tanks were documented to contain no hazardous substances (chromates and sulfates). Inventory of the majority of stored materials in the basement of the ORR was completed. Three B-25 boxes were filled with surplus materials from the basement level, mainly metals and tubing, and sent to Solid Waste Storage Area (SWSA) 6. An indicator light was repaired on the primary shutdown pump that provides circulation for the primary pool shielding water. Two new monitrons were installed, the Facility Radiation and Contamination Alarm System (FRCAS) monitoring panel was repaired, and the FRCAS was placed back on line. Approximately $200 \mathrm{ft}^{3}$ of PCB-contaminated waste was removed from the ORR heating and ventilation system duct work.

\subsubsection{Homogeneous Reactor Experiment}

At the Homogeneous Reactor Experiment (HRE) this year, fire extinguishers were installed to meet OSHA and fire code standards. The Quality Department made DOP tests on high efficienty particulate air (HEPA) filters and approved the high bay system for extended service. Water samples were taken from process cells at HRE to assess the contents before pumping water contaminated with low-level liquid waste (LLLW) from the Storage Pool to a tanker for treatment at the ORNL Waste Evaporator. The analysis conducted was for hardness (presence of calcium or magnesium ions in solution) in order to determine the feasibility of treatment of the waste through evaporation. Thirty $\mathrm{ft}^{3}$ of metals was placed into a "clean" metal dumpster, and a subsequent characterization was performed on a portion of the high bay area for implementation of RADCON regulations involving "fixed" contamination. According to RADCON guidelines, entrapped contamination was fixated by applying paint to the floor areas in a pattern to allow walkways through portions of the HRE high bay used for S\&M activities. Based on RADCON guidance, two coats are required, a magenta undercoat and a top coat. A diversion pipe was installed on a pipe that normally transports liquid from the control room sump to the $12,000 \mathrm{gal}$ tank (7562). This valve and pipe extension was placed in the current line at the HRE Storage Pool to divert water from entering the 12,000-gal LLLW storage tank in excess of the volume capacity of the tank. This connector allows manual diversion through alternate valving into the storage pool based on input level trends in the 12,000-gal LLLW tank. New covers were installed on the absorber and absorber valve pits to avert rainwater from draining into the pits and potentially leaking from a nonpermitted outfall directly east of the pits. Approximately $18 \mathrm{ft}^{3}$ of tile containing asbestos was removed from HRE to correct OSHA deficiencies for broken tiles laden with asbestos fibers. The removal was conducted under Industrial Hygiene oversight. An earlier occurrence on the same tile was reported and successfully closed out on 8/16/93, as reported in ORO-MMES-X10WSTEMRA-1992-0011, "HRE Control Room Asbestos Tile Unauthorized Removal." (ORNL Plant Maintenance personnel used nonqualified personnel to initiate tile removal in the Control Room at HRE.) All slings, chokers, and lifting fixtures were checked by Quality Assurance and Inspection (QA\&I) to identify any deficiencies. None were located. A flow meter was installed on the sump pump in the basement control room area to measure water sent to the 12,000-gal LLLW tank. The facility checklist was revised to document these water transfers. To date, approximately $4500 \mathrm{gal}$ has been pumped to the storage tank and LLLW tank. Approximately $500 \mathrm{ft}^{3}$ of noncontaminated scrap metal, which was associated with the support cells of the reactor, was removed from the HRE. 


\subsubsection{Oak Ridge Graphite Reactor}

At the Oak Ridge Graphite Reactor (OGR) this year, fan guards were installed on all McQuay heaters to meet OSHA requirements. The flammable storage cabinet was upgraded to include a new grounding strap and additional vents for the increased volume of flammables stored there. Thirty-six $\mathrm{ft}^{3}$ of contaminated solid waste consisting of a drip pan previously used for the waste scrap carrier and several hatch covers were removed from the OGR and sent to SWSA 6. All hoisting cables were removed from the second level of the OGR and replaced with new QA\&I-approved chokers to respond to new ORNL directives on hoisting and rigging activities.

\subsubsection{Low-Intensity Test Reactor}

At LITR, several areas (approx. $80 \mathrm{ft}^{2}$ ), were retiled to restore walkways necessary to conduct S\&M activities. The old tiles had been broken during past operations at LITR and violated current OSHA standards for asbestos in personnel areas. Also, approx. $3 \mathrm{ft}^{3}$ of lead bricks were removed from the LITR following characterization and returned to the ORNL Lead Shop for further use. A new closed-tube manometer was installed on the primary containment and off-gas line for measurement of vacuum on the LITR primary containment cooling system components.

\subsection{OTHER SURPLUS FACILITIES SURVEILLANCE AND MAINTENANCE}

\subsubsection{High Level Chemical Development Laboratory}

This year at the High Level Chemical Development Laboratory (HLCDL), the sodium hydroxide supply tank on the east side of 4507 was pumped of approximately 35 gal of $23 \%$ solution. Based on the results of sampling by Analytical Chemistry and ORNL Waste Operations Department, the liquid was pumped to a nearby process waste drain. The tank was then flushed (three flushes) to remove residual sodium hydroxide to the same process drain. The tank was left empty.

Faulty chart drivers on the readouts of two CAAMs were repaired following several alarms. The ORNL Laboratory Shift Supervisor determined that the alarms were not reportable incidences.

In-leaking groundwater was pumped out of a sump in the downstream vent duct servicing hot cells vacuum for the HLCDL. This was accomplished to alleviate several previous alarms for low and cycling vacuum on the hot cells at the facility.

\subsubsection{Old Hydrofracture Facility (Building 7852)}

Routine surveillance and maintenance was conducted at the Old Hydrofracture Facility (OHF) this year. Routine S\&M includes routine site inspections, completion of facility checksheets and logbooks, radiological and industrial hygiene surveillance, and routine mairtenance activities required as a result of site inspections. Maintenance of containment systems and equipment, general facility upkeep, and ground maintenance are included. 


\subsubsection{Shielded Transfer Tanks}

Routine surveillance and maintenance was conducted at the shielded transfer tanks this year with no increase in surface contamination, as indicated by the quarterly radiological inspections. This is due in part to last year's installation of the canopy over all five tanks, which diverts rainwater from them.

\subsubsection{Fission Product Pilot Plant (Building 3515)}

Routine surveillance and maintenance was conducted at the Fission Product Pilot Plant this year. Routine S\&M includes routine site inspections, completion of facility checksheets and logbooks, radiological and industrial hygiene surveillance, and routine maintenance activities required as a result of site inspections. Maintenance of containment systems and equipment, general facility upkeep, and ground maintenance are included.

\subsubsection{Waste Evaporator Facility (Building 3506)}

Routine surveillance and maintenance was performed as scheduled at the Waste Evaporator this year. Routine S\&M includes routine site inspections, completion of facility checksheets and logbooks, radiological and industrial hygiene surveillance, and routine maintenance activities required as a result of site inspections. Maintenance of containment systems and equipment, general facility upkeep, and ground maintenance are included.

\subsubsection{Fission Product Development Laboratory}

Routine surveillance and maintenance was conducted at FPDL this year. Routine S\&M includes routine site inspections, completion of facility checksheets and logbooks, radiological and industrial hygiene surveillance, and routine maintenance activities required as a result of site inspections. Maintenance of containment syste' $n$ s and equipment, general facility upkeep, and ground maintenance are included. A hole in the floor adjacent to the cells was repaired, alleviating a tripping hazard that was noted as an OSHA violation.

\subsubsection{Metal Recovery Facility}

Routine surveillance and maintenance was performed as required; no abnormal situations were encountered. New compressor belts and HEPA filters were installed in the building ventilation system. A structural assessment was conducted of the Metal Recovery Facility (MRF) roof; a suspect area was identified, and personnel are no longer allowed to traverse the area. All equipment and debris was removed from the shop in the southeast corner of the building.

\subsubsection{Molten Salt Corrosion Loop}

A safety inspection was conducted this year at 9201-3, Mo!ten Salt Corrosion Loop, by the WMRAD Safety Department, and several deficiencies were noted. A complete characterization of the accessible area was conducted following the findings by Radian personnel, and the area was rezoned. Also, several surplus fluorescent light bulbs were discarded. 


\subsubsection{Coolant Salt Technology Facility}

A safety inspection was conducted this year at 9201-3, Coolant Salt Technology Facility (Tritium Test Loop), by the WMRAD Safety Department, and several deficiencies were noted. Several lines leading from the main structure are not properly labeled as associated with the facility. Labels were affixed and other markings added to properly identify the structure.

\subsubsection{Decontamination Facility (9419-1)}

A safety inspection was conducted this year at 9419-1, Decontamination Facility, by the WMRAD Safety Department, and several deficiencies were noted. An action plan was developed to remove accessible wastes from within the building. The Y-12 Maintenance Department was notified that a leak in the north end of the facility needs repairing. These actions will be completed in FY 1994 as a special maintenance project.

\subsubsection{Storage Tank}

A safety inspection was conducted this year at the Storage Tank in 9201-3 by the WMRAD Safety Department, and several deficiencies were noted. Signs were posted to ensure that personnel take proper precautions before entering the tank area, and a lock and hasp were placed at the entrance to maintain access control. 


\section{SPECIAL MAINTENANCE PROJECTS}

\subsection{MOLTEN SALT REACTOR EXPERIMENT CONTAMINATION MIGRATION STUDY}

Several activities were conducted in FY 1993 in preparation for assessment of the stability of the fuel salts in their current configuration in the MSRE Drain Tanks for continued storage. First, a baseline was established of ${ }^{232} U$ and daughter activity at the drain tank purge lines in the NESA. Secondly, a sampling plan was developed and extensive planning conducted to withdraw a gas and/or aerosol sample from the Vent House line (Line 518) that once released a trace of alpha activity and to run an on-line mass analysis. These samplings will potentially provide explanations to the potential migration mechanisms and determine if $\mathrm{UF}_{6}$, fluorine, and fluorine compounds, such as $\mathrm{HF}$ are present.

All baseline data in the NESA were completed, the east cell face was mapped for ${ }^{137} \mathrm{Cs}$ (i.e., Barium-137m) and a fixed ratio of ${ }^{232} \mathrm{U}$ daughters activity, and the potential location of increased radiation emitters in the drain tank purge lines was located. The gamma surveys consisted of a methodical scan of the penetration plug. It was determined that the ${ }^{137} \mathrm{Cs}$ was located in the general vicinity of the Helium purge lines $(572,574$, and 576). The wall was laid out in four sections for mapping purposes; the largest amount of ${ }^{137} \mathrm{Cs}$ was in the lower left quadrant, just inside the penetration plug and beyond the vertical plane of the concrete wall.

The sampling in the Vent House has been delayed because of readiness review items, problems encountered during mock-up tests performed on the instrumentation for low molecular weight species, and required modifications of the mass analyzer's inlet and high vacuum lines to make them compatible with fluorine.

The readiness review criteria have been satisfied for the sampling, and only the dry run and associated hands-on training remain to satisfy requirements for demonstrating readiness to proceed with the sampling in the Vent House. This sampling is scheduled to be completed in the first quarter of FY 1994.

\subsection{OSHA COMPLIANCE UPGRADES}

In FY 1993, several upgrade activities were completed at the HRE and LITR to comply with findings and recommendations in FY 1992. At HRE, several electrical deficiencies in feeder breaker panels from TVA power were replaced, providing new breakers that meet current code requirements. Several pump motors were removed at the LITR. The oil was removed from the pumps, and both the oil and the pumps were disposed of. This obviated the need to install belt guards for OSHA compliance and is consistent with interim measures for proceeding with subsequent D\&D activities.

Also, several stationary ladders were repaired, and several railings were added to areas where S\&M activities are conducted to provide necessary personnel protection at these facilities. 


\subsection{SAFETY ANALYSIS REPORT UPGRADE PROGRAM}

Phase I of the ORNL Safety Analysis Report Upgrade Program (SARUP) was completed for all D\&D facilities currently in the S\&M program. The objective of Phase 1 is to identify and qualitatively evaluate all facilities that involve significant hazards, and thereby to determining the need for updated safety analysis and risk reduction action plans. All facilities except the LITR, MSRE, OGR, ORR, OHF, MRF, and HRE were screened out and required only preliminary hazard screening documentation. Formal documentation, consisting of a hazard screening document that lists the level of hazard ranking, a description of the methodology used in obtaining the ranking (based on the worst-case credible scenario for each facility), and facility-specific information, was completed in December 1992 for those facilities that were not screened out. The seven facilities listed above were ranked as "low hazard" facilities under the DOE ranking scheme of "generally-acceptable," "low," "moderate," and "high" hazards.

Future activities concerning SARUP will include a full-blown safety analysis report (SAR) for ORNL facilities screened out as "moderate" or "high" hazard facilities. MSRE may qualify because of an isotopic inventory following the completion of hazard screening in December 1992 , which identified ${ }^{239} \mathrm{Pu}$ as above the limit at which follow-up documentation is required. An SAR may not be required, but recent changes in DOE orders must be interpreted by the Office of Operational Readiness and Safety before direction is given to MSRE facility management. At a minimum, a technical safety requirements document will probably be necessary for MSRE. A limiting conditions document may be required for any "safety class items" identified at HRE, OGR, LITR, OHF, and MRF.

\subsection{OAK RIDGE RESEARCH REACTOR INSTRUMENT UPGRADE}

Activities on the ORR Instrument Upgrade included completion of a design package for annunciator consolidation and relocation inside Bldg. 3042 and the procurement and installation of an uninterrupted power supply (UPS) to replace the function of the diesel generator and associated underground diesel storage tank.

In August, Instrumentation and Controls provided a completed design package for consolidating all remaining necessary annunciators in a convenient place on the ground level of ORR and to place all signals of the Waste Operations Control Center at remote locations for continuous surveillance.

The UPS was installed in June 1992, and was field tested prior to installation and then again after hookup of all the parameters scheduled for relocation was completed. All tests were successful, and the UPS was placed on-line in July 1992. No incidences have occurred that would require the UPS to carry the load of instruments for continuous S\&M. 


\section{SUMMARY}

S\&M activities will continue in FY 1994. Routine S\&M will continue as scheduled. The MSRE contamination migration study, the OGR mezzanine-level debris removal and decontamination, OSHA upgrades, the HRE storage pool inventory, and the ORR instrument upgrade will provide the majority of special maintenance projects in FY 1994. 


\section{DISTRIBUTION}

1. H. L. Boston

2. K. L. Brady

3. H. B. Braunstein

4-6. T. W. Burwinkle

7. R. L. Chadwick

8. J. S. Colley

9. K. Constant

10. S. L. Cross

11-13. M. K. Ford

14-16. H. R. Gaddis

17. C. D. Goins

18. K. W. Haff

19. P. J. Halsey

20. J. L. Hammontree

21. R. L. Hendren

22. L. Holder, Jr.

23. J. H. Hooyman

24. D. D. Huff

25. R. G. Jones

26. G. J. Mandry

27-29. D. M. Matteo

30. G. A. Mays

31. L. E. McNeese

32. T. R. Nelson
33. C. E. Nix

34-35. P. T. Owen

36. G. E. Rymer

37. T. F. Scanlan

38. P. A. Schrandt

39. C. B. Scott

40. C. S. Sims

41. R. R. Spears

42. L. E. Stratton

43. J. H. Swanks

44. J. R. Trabalka

45. T. D. Tyler

46 L. D. Voorhees

47. D. R. Watkins

48. R. K. White

49. J. K. Williams

50. P. S. Wood

51. Central Research Library

52-54. Central ER Doc. Manage. Center

55-57. ORNL ER Doc. Manage. Center

58. Laboratory Records Department

59. ORNL Patent Section

60. RAP/RCDB

61. Office of Assistant Manager for Energy Research and Development, DOE Oak Ridge Field Office, P.O. Box 2001, Oak Ridge, TN 37831-8600

62-63. R. C. Sleeman, DOE Oak Ridge Field Office, P.O. Box 2001, Oak Ridge, TN 37831-8541

64-65. M. R. Jugan, DOE Oak Ridge Field Office, P.O. Box 2001, Oak Ridge, TN 378318541

66-67. Office of Scientific and Technical Information, P.O. Box 62, Oak Ridge, TN 37831 

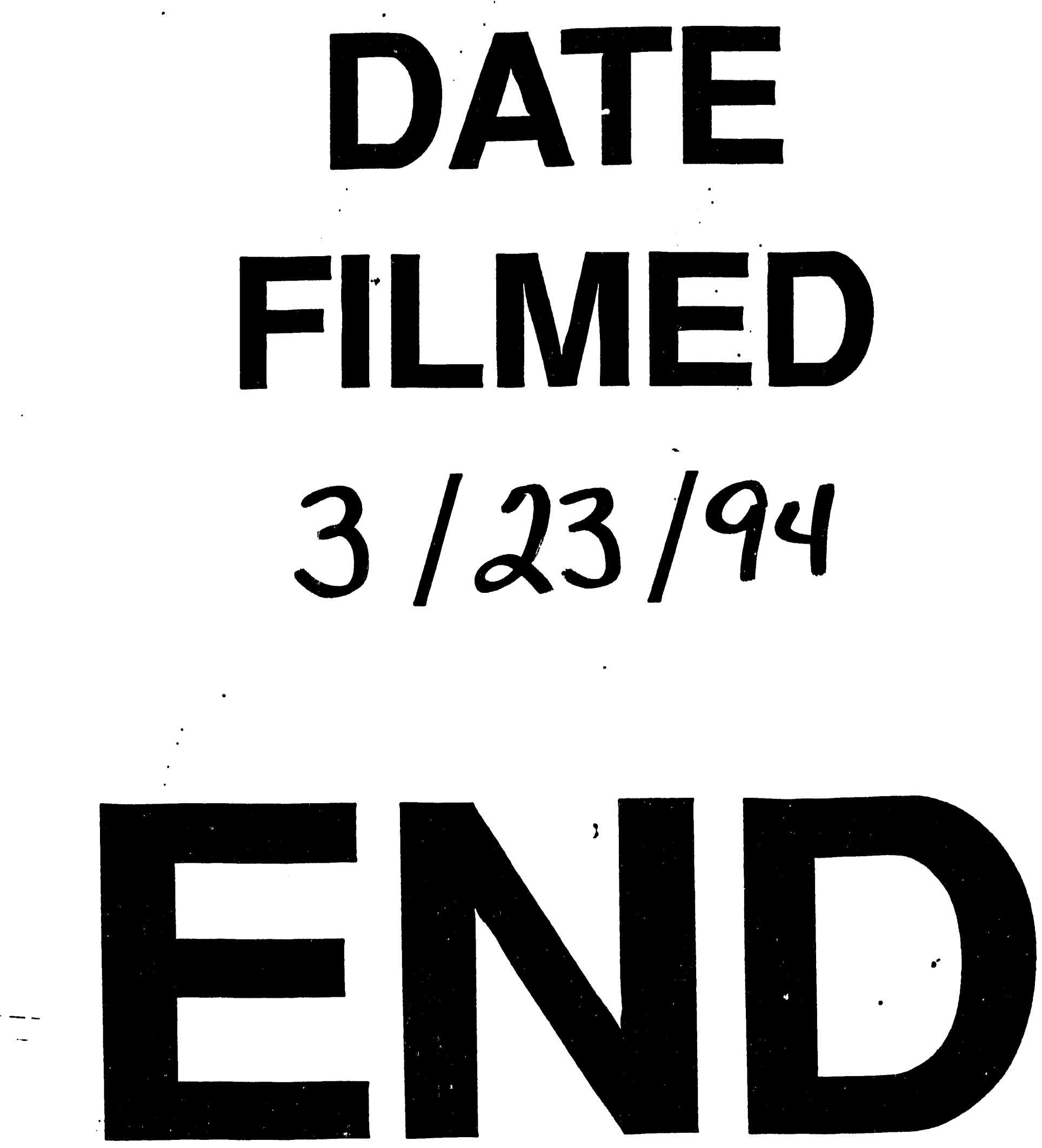
